\title{
Mother-Child Communication About Menarche And Preparation For Menarche
}

\author{
Laurensia Yunita $^{1}$, Ibrahim ${ }^{2}$, Lailatul Fitri ${ }^{3}$

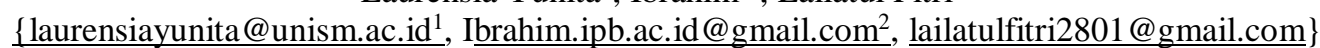 \\ ${ }^{123}$ Sari Mulia University, Banjarmasin, South Kalimantan, Indonesia \\ *laurensiayunita@unism.ac.id
}

\begin{abstract}
Menarche is an early menstruation in a female adolescents. Therefore every female adolescents will change different reactions to completing menstruation. The factor influencing the readiness of female adolescents in menarche is mother-child comunication. The role of the mother is very important in the process of growth and development of children, especially when the child gets his first menstruation. If the mother does not provide adequate information to her child about the first menstruation, child anxiety will arise. In fact, there is often a belief that menarche is a serious thing like an illness. So, importance of communicate mother about the readiness their daugher in the face of menarche. Survey study uses a cross sectional approach. The research sample of 43 people was taken by random sampling, As many as 43 students (female adolescents) were given questions about mother's communication and readiness of female adolescents in menarche. The results of this study stated the communication of mothers to female adolescents in the menarche meeting was mostly categorized as less and the readiness of female adolescents discussing menarche was categorized as no ready.
\end{abstract}

Keywords: Adolescent, Communication, Parents, Preparation, Menarche

\section{Introduction}

According to WHO (World Health Organization), adolescents are residents in the age range of 10 to 19 years, while the Ministry of Health regulation of the Republic of Indonesia number 25 of 2014, adolescents are residents in the age range of 10-18 years. Meanwhile, according to the National Population and Family Planning Agency (BKKBN) the age range of teenagers is 10-24 years and not yet married. Based on the projected population of Indonesia in 2015 shows that the number of adolescents (aged 10-24 years) reaches more than 67 million people or $25 \%$ of Indonesia's population of 255 million, meaning that 1 out of every 4 Indonesians is teenagers. The number of female adolescent in Indonesia reaches 21 million. In 2013 female adolescence in Indonesia experienced an increase of 22 million [1].

Teenagers are a period of development in which individuals experience changes from childhood to adulthood. Reproductive health is an important issue to get attention especially among adolescents. Reproductive health must be introduced early, therefore adolescents are entitled to the fulfillment of their reproductive health. Especially for Female, the introduction of reproductive health is also intended for children to prepare themselves for the coming of 
menarche which is a sign of puberty and generally experienced by adolescents at school age $[2]$.

Menarche is the first bleeding from the uterus as the start of menstruation in a woman. Menarche usually appears at the age of 11-14 years. Therefore every girl will experience a variety of different reactions in the face of her first menstruation. As for some of the reactions that are usually experienced by adolescents who experience menarche include fear, anxiety, confusion, and shame [3].

The Indonesian Youth Reproductive Health Survey conducted in 2017 found that teenage girls discussed with their parents by $45 \%$, while for friends by $58 \%, 15 \%$ with teachers and $20 \%$ did not discuss with anyone. Teenagers usually do not know about the basic changes that occur in him. So that if adolescents are not informed or not well prepared about their physical and psychological changes during puberty, the experience of physical changes will be a traumatic event. As a result, adolescents will develop unfavorable attitudes towards these changes [4].

Teenagers who are about to experience their first menstruation need good mental readiness. Readiness in facing menarche shows that a person is ready to reach physical maturity that is the arrival of the first menstruation at the age of ten to sixteen years that occurs at certain times and recur. Therefore, the readiness of these adolescents needs support from parents, especially mothers. The role of the mother is very important in the process of change that occurs in children both physically and mentally. Generally, adolescents who experience menarche will tell their mothers, but if it is not balanced by providing appropriate information and mothers want to openly explain this to children, then this condition will cause anxiety in children, often even children will see this menache as a disease [5]. Information about reproductive health that must be provided by parents includes wet dreams, menstruation, large showers, marital relations, pregnancy, STDs, and narcotics and illegal drugs. So far, relatively few adolescents have received information about reproductive health from parents / family [4]

The results of [6] showed that $31.2 \%$ of female adolescents were in the category of not ready for menstruation and had negative responses about menarche such as feeling scared, surprised, sad, disappointed, embarrassed worried and confused. Ramadhaniyati's research at SDN 53 Kubu Raya shows that $80 \%$ of grade V students are afraid, anxious, confused, and embarrassed when asked about menstruation. The results of the research analysis also mentioned that the lack of information obtained in detail in dealing with menarche [7].

Based on a preliminary study conducted on February 6, 2017 at MTS Siti Maryam Banjarmasin class VII by interviewing 10 students about knowledge of menstruation. The results are known that 9 out of 10 students say they have experienced menstruation first and the average age is 10-13 years. There are 7 students who have never gotten information about menstruation and 3 students who have gotten information about menstruation from their mothers. A total of 6 students said they were shocked, scared and embarrassed, while 3 students said they were normal and 1 student said that they were eager to have menstruation. Lack of communication between mother and child regarding menstruation is likely due to the lack of parental education and neglects communication. Based on the above background, researchers are interested in conducting research on mother-child communication in preparation for menarche

\section{Method}

This research is a quantitative research using analytic survey study method with Cross Sectional approach. The population is all female students of MTs Siti Maryam Banjarmasin 
who have or have not had menstruation totaling 77 people. The sample data amounted to 43 people using simple random sampling. Data retrieval uses a questionnaire with univariate analysis and data is presented through the percentage calculation table.

\section{Results}

\section{Characteristics Of Respondents}

\section{Mother job}

Table 1 Frequency Distribution of Mother Job

\begin{tabular}{lll}
\hline Mother Job & $\begin{array}{l}\text { Frekuensi } \\
(\mathrm{n})\end{array}$ & $\begin{array}{l}\text { Procentage } \\
(\%)\end{array}$ \\
\hline Housewife & 31 & 72,1 \\
Trade & 9 & 20,9 \\
Farmer & 1 & 2,3 \\
Enterpreneur & 1 & 2,3 \\
Teacher & 1 & 2,3 \\
\hline Amount & 43 & 100 \\
\hline
\end{tabular}

Based on Table 1, a description of the characteristics of respondents based on the work of mothers from 43 respondents involved in this study was dominated as $72.1 \%$ Housewife, Traders as much as $20.9 \%$ and the rest worked as farmers, private sector and teachers.

\section{Last Education Parents}

Table 2 Frequency Distribution of Parents Last Education

\begin{tabular}{lll}
\hline Education & $\begin{array}{l}\text { Frekuensi } \\
(\mathrm{n})\end{array}$ & $\begin{array}{l}\text { Procentage } \\
(\%)\end{array}$ \\
\hline Bachelor & 1 & 2,3 \\
Senior High School & 14 & 32,6 \\
Junior High School & 11 & 25,6 \\
Elementary School & 15 & 34,5 \\
Tidak Sekolah & 2 & 4,7 \\
\hline Amount & 43 & 100 \\
\hline
\end{tabular}

Based on Table 2, it was found that the majority of mothers with the last education, namely Elementary School as many as 15 people (34.9\%). 32.6\% of mothers with a high school education and $25.6 \%$ of junior high school. 


\section{Analysis of Univariate}

Mother comunication to children and Preparation for Menarche

Table 3 Frequency Distribution of Mother comunication to children and Preparation for Menarche

\begin{tabular}{lllllll}
\hline \multirow{2}{*}{$\begin{array}{l}\text { Mother } \\
\text { comunication } \\
\text { to children }\end{array}$} & \multicolumn{2}{l}{ Preparation for Menarche } & \multicolumn{2}{l}{ Amount } \\
\cline { 2 - 6 } & $\mathrm{n}$ & $\%$ & $\mathrm{~N}$ & $\%$ & $\mathrm{~N}$ & $\%$ \\
\cline { 2 - 6 } & $\mathrm{n}$ & 30,2 & 5 & 11,6 & 18 & 41,9 \\
Often & 7 & 16,3 & 18 & 41,9 & 25 & 58,1 \\
\hline Amount & 20 & 46,5 & 23 & 53,5 & 43 & 100 \\
\hline
\end{tabular}

Based on Table 3 obtained by communication frequency of mothers from 43 respondents involved in the communication mother to child is still less $25(58.1 \%)$ and that adolescents not ready to which amounted to $23(53.5 \%)$. The table also shows $41.9 \%$ of Female Adolescents who are not ready to face menarche due to lack of mother communication.

\section{Discussions}

\section{Mother comunication to children}

Communication is the delivery of a person's statement to others. Communication is also a process of transferring understanding in the form of ideas or information from one person to another person [8]. Parent and child communication can be said to be effective if both parties are close to each other and pleasant communication is formed with openness so that selfconfidence grows [9]. This communication is important when teenagers have puberty problems. Puberty is characterized by rapid physical changes that are protected by hormonal changes. In adolescent girls puberty is marked by the presence of the first menstruation or menarche. Menarche is the stage of developing the compilation of reproductive organs to reach maturity [10]. The role of the family, especially mothers, is very important in introducing menarche to female adolescents so that they are ready to face menarche.

The results showed that $58.1 \%$ of respondents stated that mothers lack communication in partners. This shows the lack of communication between mother and child about menarche. Based on research it can be seen that most respondents who have good communication to communicate are indeed more ready to communicate compared to respondents who have poor communication to communicate. This explains the preparation of the communication preparation for the mother of the child. In line with[6], this study found that mother to child communication provides a $30 \%$ role in the readiness of students in achieving menstruation that has been completed (menarche). Female adolescents need support including communication 
from mothers or those around them in the face of menarche [11]. Attention from parents is one of the psychological factors for children, this information needs are not met will cause the child to not know how to deal with menarche and not ready to deal with it. This is in line with [10] which states that effective communication between mother and child will help the child to adjust when increasing the first menstruation (menarche).

Based on Table 2, different parental education will influence the way parents are referred to and explain menstrual problems to their daughters. Highly educated parents more easily explain about parents who are poorly educated so that information is more easily accepted by their daughters in providing information introducing the problem of menarche. In accordance with the opinion of [12] if parents have a good level of education then they also have good experience and knowledge in educating children about menstruation. Parents who have higher education and knowledge will be more active in providing understanding and information to children whose puberty is their teenage daughters.

Based on the answers to the questionnaire that has been received by respondents can be seen in the negative responses No. 4 namely "I am more comfortable when telling stories / vent with others than with my mother" reaching $65.1 \%$ who answered agree. Negative statement No. 11 which is "My mother never explained the changes that occurred when I started adolescence. For example menstruation, unstable transitions, physical changes ", the results of $62.8 \%$ who answered agree. Positive statement No. 2 "My mother often spends discussing or talking about me about my first menstrual experience" resulting in $76.7 \%$ who answered disagree. Positive statement No. 18 "My mother and I can open and accept compilation messages received" as many as $79.1 \%$ answered disagree.

Based on respondents' answers, it can be seen that communication made by mothers to children is still lacking about menarche because there are still many parents who are not open and assume that the problem is taboo to be discussed before menstruation comes. Many parents do not want to explain menstruation and changes when they reach adolescence because their children think their children are still young and will know for themselves, while there are still many children who are shy to ask teachers or parents about menstruation and they are more comfortable to tell stories or ask his friend instead of telling his mother. This is related to the study of [13] about the knowledge of Meghalaya (India) teenagers about menstruation showing 50\% of knowledge about menstruation was obtained by teenagers from friends, $36 \%$ knowledge about menstruation was obtained from mothers and $19 \%$ was obtained from immediate family.

The work of parents, especially mothers will have a big impact on the socio-economic, and the mindset of someone, so parents able to provide for her financially, but tend to be more indifferent to her child or not there is a lot of time with her, so that the child is less flexibility in telling or asking in things about menstrual problems. Parents should spend a little time for their children because parents have a responsibility to provide an explanation or information about menstruation to her daughter so that children understand better and ready to face menarche [14].

Addition to information obtained by adolescents from families (mothers or siblings), readiness to face the first menstruation (menarche) is also influenced by exposure to 
information obtained from television, radio, magazines or journals [15]. The amount of information about menarche from various sources is sometimes not matched by a selective attitude, so the information they obtain cannot be ascertained. As many as $81.95 \%$ of the information sources obtained by adolescents about menarche are mostly incorrect [16]. This causes adolescent perceptions of menarche to be negative.

Communication built by mothers to female adolescents in the face of menarche can reduce anxiety or negative perceptions of menarche. The better the interaction between the child and the mother, the more comfortable and the less anxiety so that they have good readiness in dealing with menarche. Interaction that is well established will cause closeness between female adolescents and mothers so that female adolescents are more open to the changes that occur in him.

\section{Preparation for Menarche}

The results showed that the majority of respondents were not ready to face menarche which is $53.5 \%$. This explains that respondents still do not have mental readiness when facing Menarche. Readiness to face menarche is a state of someone ready to reach physical maturity that is the arrival of the first menstruation (menarche) that occurs periodically (at a certain time) and cyclic (repeatedly). This is marked by a deep understanding of the menstrual process so that it is ready to accept and experience first menstruation (menarche) as a normal process.

Based on the results of the questionnaire answers that have been filled by respondents regarding the readiness to face menarche can be seen in the statement No. 11 which is "I am not ready to face menstruation because I see menstruation is a bother" as many as $69.8 \%$ answered yes. Statement No. 12 namely "I am afraid of facing menstruation because I have seen people when they are menstruating can not go anywhere" as many as $67.4 \%$ answered yes. Statement No. 20 i.e. "I am afraid of having menstruation because my friend said that menstruation hurts stomach" as many as $79.1 \%$ answered yes. The three statements above are negative statements. This means that there are still many respondents who are not ready to menarche. Based on the results of respondents' answers it can be seen that in general respondents who are not ready to face menarche because of several things including not being ready for menstruation if they have never seen another person menstruate, menstruation is troublesome and the stomach hurts and cannot go anywhere. Research [16] also mentioned that there are still many children who are not good towards menarche, which is as much as $73.08 \%$. They assume that menarche is an unpleasant new burden.

According to [17] there are thee aspects of readiness. The first aspect is understanding, that is, one's experience of the events they experience. When someone understands and know what will happen to them, this can help him to do things that happen. The second aspect is appreciation. This aspect is a condition where someone is ready, everything that happen will happen to everyone. This is also something natural, normal and not to worry about. The weekly aspect is willingness, it is a direct action on the opportunuties that are present, so they become part of life experience. Comparison between young women who are prepared with those who are not in the firts mentrual period is shown by a positive 
attitude (ready) and negative (not ready). Adolescent gils who tend to feel negative inconvenience, dirtiness, discomfort so that limited activity and emotional fluctuations. Many reasons lie behaid the unprepared teenage gils in the first menstrual difficulites. Like, parents lack of sex education in children. Sex education is a modern property, while this has always been done. That way, gils will not accept anxienty and are more positive in responding to the arrival of the first menstruation which has an impact on physical and psychological changes.

According to the previous study [18], communication about menarche is very important for female adolecents. Communication is the process of transferring understanding in the form of ideas or information from one person to another person. Communication is interpreted as the process of delivering information or sending from one person to another person. result of study communication made by mother to child is still lacking about menarche because there are still many parents who are not open and assume that the problem is taboo to be discussed before menstruation comes. Many parents do not want to explain about menstruation and changes when they reach adolescence because their children think their children are still young and will know for themselves, while many children are shy about asking teachers or parents about menstruation and they are more comfortable telling stories or ask his friend instead of telling his mother [19]

\section{Conclusion}

Based on the results of the study it can be concluded that the readiness of menarche is a condition which shows that a person is preparing one of physical maturity, namely the arrival of the first menstruation (menarche) as a normal process. The readiness of women in menarche conversations is also driven by the level of knowledge of children about menstruation. Knowledge about menstruation can be obtained from various sources of information such as family, peer groups, school environment, and media both print and electronic. Mother's communication about menarche can reduce the minds of adolescent girls who get wrong information and link menstruation with something negative. This condition ultimately causes the child to become unprepared to receive menarche and correct the difficulties in dealing with it.

\section{References}

[1] Badan Kependudukan dan Keluarga Berencana Nasional. 2010. Kebijakan Teknis Penanggulangan Masalah Kesehatan Reproduksi Melalui Program KB Nasional. Jakarta: BKKBN.

[2] Dinas Kesehatan Kota Banjarmasin. 2015. Profil Kesehatan 2015 Kalimantan Selatan. Banjarmasin: Dinas Kota Banjarmasin.

[3] Wong.2010. Maternal Child Nursing Care. (2nd Ed). St Louis: Mosby Elsevier

[4] Hurlock, EB. 2004 Psikolongi Perkembangan: Suatu Pendekatan Sepanjang Rentang Kehidupan. Edisi ke-5 Jakarta: Erlangga

[5] Llewellyn-Jones, D. 2005. Setiap Wanita: Panduan Terlengkap tentang Kesehatan, Kebidanan dan Kandungan. PT. Delapratasa Publishing 
[6] Fajri, and M. Khairani. Hubungan Antara Komunikasi ibu anak dengan kesiapan menghadapai menrtuasi pertama (menarche) pada siswi SMP Muhammadiyah Banda Aceh. Jurnal Psikologi. Mar 2012. Vol.10 no.2 pp 133-143

[7] Ramadhaniyati. 2014. Pengaruh komunikasi ibu tentang menstruasi terhadap kesiapan anak menghadapi menarche pada siswi kelas V SD N 53 Kubu Raya tahun 2014. Jurnal Keperawatan dan Kesehatan. 3(1): 39-46.

[8] Bahri, Syaiful. 2004 Pola Komunikasi Orang tua dan anak dalam keluarga Jakarta: PT Reneka Cipta

[9] Rahmat, Jalaludin, 2007. Psikologi Komunikasi. Bandung PT Remaja Rosdakarya

[10] Sarwono, S.W. 2010. Psikologi remaja. Jakarta:Rajawali Pers

[11] Utami, S. 2008. Hubungan Antara Dukungan sosial ibu dengan Kecemasan Menghadapi Menarche Pada remaja putri PraPubertas. Fakultas Psikologi dan ilmu sosial Budaya Universitas Islam Indonesia.

[12] Agustini, L. 2012. Gambaran tingkat Pengetahuan dan Praktik Orang tua Siswi Kelas 4 dan 5 Sekolah Dasar Islam Alazhar 14 Semarang Dalam Memberikan Edukasi Tentang Menstruasi.

[13] Nagar, S. \& Aimol, R. 2010.Knowledge of Adolescent Girls Regarding Menstruation in Tribal Areas of Meghalaya.India : Department of Human Development. College of Home Science Journal 8(1).24-285

[14] SDKI. Survei Demografi dan Kesehatan Indonesia.2012. Kesehatan Reproduksi Remaja (KRR) tahun 2012.Jakarta: Kementrian Kesehatan RI.

[15] Hendrik. 2006. Problema Haid (Tinjauan Syariat Islam dan Medis). Solo: Tiga Serangkai

[16] Jayanti, N.F. dan Purwanti, S. 2012. Deskripsi faktor-faktor yang mempengaruhi kesiapan anak dalam menghadapi menarche di SD Negeri 1 Kretek kecamatan Paguyangan kabupaten Brebes tahun 2011.Jurnal Ilmiah Kebidanan.

[17] Yusuf, S. 2010. Psikologi perkembangan anak dan remaja (edisi revis). Bandung: PT. Remaja Rosdakarya

[18] Deddy dan Rivai. 2009. Kepemimpinan dan Perilaku Organisasi. Jakarta: Rajawali Per. Rohim

[19] Aboyeji. 2015. Peran Ibu Dalam Perubahan Psikologi Remaja Saat Mengalami Menarche. Skripsi. Program Sarjana UNDIP. Semarang 